\title{
The Effect of Growth Medium pH towards Trypsin-Like Activity Produced by Lactic Acid Bacteria
}

\author{
DYAH WULANSARI, BUDIASIH WAHYUNTARI, TRISMILAH, \\ AND ASTUTIATI NURHASANAH*
}

\begin{abstract}
Laboratory for the Development of Agroindustrial and Biomedical Technology (LAPTIAB), BPPT, Gedung 611, Kawasan PUSPIPTEK Serpong, Tangerang Selatan, Indonesia
\end{abstract}

\begin{abstract}
In cases of pancreatic disease, trypsin deficiency often occurs due to reduced expression of trypsin in the pancreas. Patients with pancreatic problem can be treated with a supplement containing digestive enzymes, including trypsin. However, most of the enzymes currently used for the treatment are derived from porcine and bovine sources. On the other hand, lactic acid bacteria are also known to show trypsin-like activity. In the previous work, our group screened 11 lactic acid bacteria isolates, which had previously been proven to show serine protease activity, for trypsin-like activity. The strains were initially grown in MRS (de Mann, Rogosa and Sharpe) medium before being transferred directly to the production medium to produce trypsin. During the previous study, the initial $\mathrm{pH}$ of the production medium was set at 6 (the same as the MRS medium $\mathrm{pH}$ ), which is the optimum $\mathrm{pH}$ for the cell growth of lactic acid bacteria. However, most trypsin has an optimum $\mathrm{pH}$ of around 8 . In this study, we altered the production medium $\mathrm{pH}$ to 8 and we harvested the lactic acid bacteria from MRS medium by centrifugation prior to their inoculation to the production medium. Observation of the culture growth and enzyme activity indicated that the new strategy improved the enzyme activity expressed by some strains.
\end{abstract}

Key words: lactic acid bacteria, trypsin, trypsin-like activity

Pada kasus-kasus gangguan pankreas, defisiensi tripsin seringkali terjadi karena berkurangnya ekspresi tripsin di pankreas. Pasien dengan masalah pankreas dapat ditangani dengan pemberian suplemen enzim pencernaan. Meskipun demikian, sebagian besar enzim yang digunakan untuk pengobatan saat ini didapatkan dari babi atau sapi. Di sisi lain, bakteri asam laktat juga diketahui menunjukkan aktifitas seperti tripsin. Dalam penelitian di grup kami sebelumnya, dilakukan skrining terhadap 11 isolat bakteri asam laktat untuk mendapatkan isolat yang menunjukkan aktifitas seperti tripsin. Isolat-isolat ini sebelumnya telah terbukti memiliki aktivitas protease serin. Isolat-isolat tersebut ditumbuhkan dalam medium MRS (de Mann, Rogosa and Sharpe) sebelum dipindahkan ke medium produksi untuk memproduksi tripsin. Pada penelitian sebelumnya, medium produksi diatur pada $\mathrm{pH}$ awal 6 (sama dengan $\mathrm{pH}$ medium MRS). Namun demikian, kebanyakan tripsin bekerja pada $\mathrm{pH}$ optimum 8 . Dalam penelitian kali ini, kami mengubah $\mathrm{pH}$ medium produksi menjadi 8 dan melakukan pemanenan sel dengan cara sentrifugasi sel starter dari medium MRS sebelum digunakan untuk menginokulasi medium produksi. Observasi terhadap pertumbuhan kultur dan aktivitas enzim menunjukkan bahwa strategi baru ini meningkatkan aktifitas enzim yang dihasilkan oleh beberapa isolat.

Kata kunci: aktivitas seperti tripsin, bakteri asam laktat, tripsin

Trypsin is a protease enzyme produced by the pancreas and secreted to the duodenum, where it hydrolyses proteins into peptides during the digestion of food. Trypsin is a member of the serine protease family, which digests protein from the carboxyl terminal (C-terminal) of the amino acids lysine (Lys) and arginine (Arg), unless these amino acids are bound to proline (Pro) on their C-terminal (Whitcomb and Lowe 2007).

In cases of pancreatic insufficiency, the capability to produce and/or to transport digestive enzymes, including trypsin, is not sufficient, thus affecting the digestion processes. For this reason, patients with pancreatic insufficiency often show symptoms of

*Corresponding author; Phone: +62-21-7560536, Fax: +6221-7566922; E-mail: anpratomo@yahoo.com malabsorption, malnutrition, vitamin deficiency and weight loss, or in children shown by lack of weight gain (Pezzilli 2009). Pancreatic enzymes have often been used to treat patients with digestion problems caused by a pancreatic defect (Waljee et al. 2009). It has been reported that digestive enzyme treatment was proven to increase the fat absorption coefficient of the patients (Waljee etal.2009).

Lactic acid bacteria (LAB) have long been used in food processing. Those which are most commonly used are Lactococci, Lactobacillus bulgaricus (Courtin et al. 2002; Oberg et al. 2002), L. rhamnosus (Haq et al. 2006), L. casei (Piuri et al. 2003), L. paracasei (Bintsis et al. 2003; Haq and Mukhtar 2006), L. helveticus (Oberg et al. 2002), L. delbrueckii (Oberg et al. 2002), $L$. brevis, L. cellobiosus, L. fermentum, and $L$. plantarum (Haq and Mukhtar 2006). In addition, 
several bacteria from the genus Lactobacillus are known to have proteolytic activity (Caplice et al. 1999; Haq and Mukhtar 2006).

Proteolysis of milk proteins by LAB plays an important role in providing peptides and amino acids to cover the demand of the bacteria and previously several LAB known to have trypsin-like activity have been isolated (Wulansari et al. 2010). The screening was performed on isolates previously known to show serine protease activity (Wulansari and Wahyuntari 2010). The strains used to produce the enzyme were cultured in two stages, the growth stage and the production stage. During the growth stage, the strains were cultured in MRS (de Mann, Rogosa and Sharpe) medium, whilst during the production stage, the strains were cultured in the production medium (Glucose $0.5 \%$, Yeast Extract 0.1\%, Skim Milk 1\%, pH 6) (Wulansari and Wahyuntari 2010). In this project, a medium with $\mathrm{pH} 8$ was used and prior to inoculation to the production medium, cells were harvested from the growth medium by means of centrifugation.

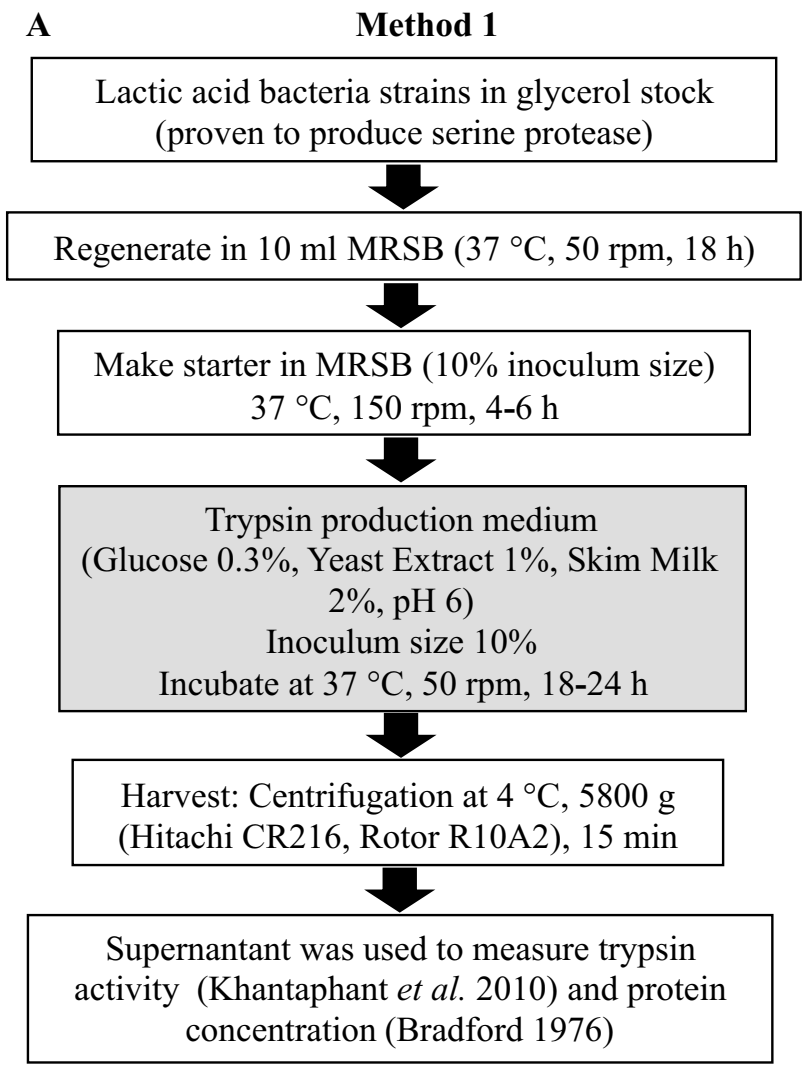

\section{MATERIALS AND METHODS}

Strains and Media. The strains used in this study (listed in Table 1) were from the collection of Centre for Bioindustrial Technology, BPPT, Indonesia.

The medium used for growth of the lactic acid bacteria was the MRS medium (Oxoid CM0359), which was autoclaved at $121^{\circ} \mathrm{C}$ for $15 \mathrm{~min}$.

The media used for trypsin production contains glucose $0.3 \%$; yeast extract $1 \%$; skim milk $2 \%$; pH 6 or 8 , and was autoclaved at $121{ }^{\circ} \mathrm{C}$ for $15 \mathrm{~min}$.

Culture. Strains from $40 \mu \mathrm{L}$ glycerol stocks were regenerated in $4 \mathrm{~mL}$ MRS medium broth incubated at $37^{\circ} \mathrm{C}$, shaking at $50 \mathrm{rpm}$ for 18 hours. The culture was then used to inoculate fresh MRS medium broth $(1 \%$ inoculum) which was incubated at $37{ }^{\circ} \mathrm{C}$ with shaking at $50 \mathrm{rpm}$ for 4-6 hours. This starter was then used to inoculate the trypsin production medium. Two kind of production media and methods were used and compared(Fig 1).

Method 1. Starter was used to inoculate production

B

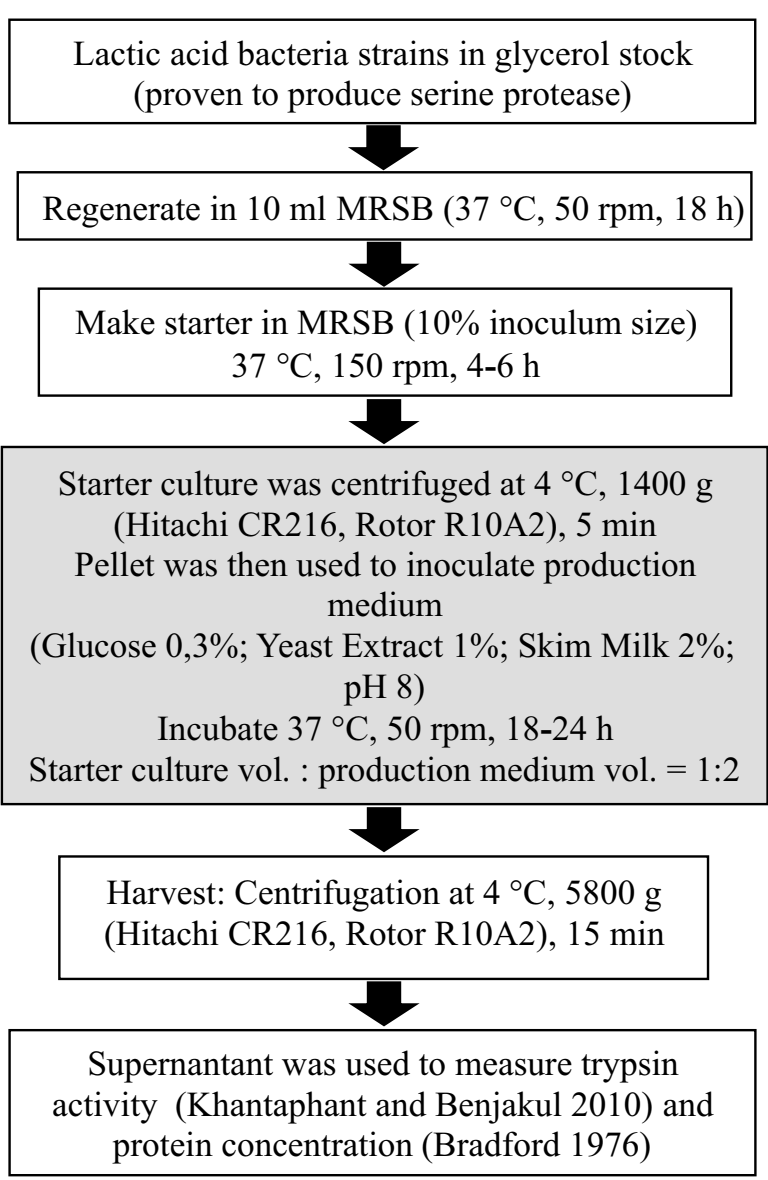

Fig 1 The methods used in the cultivation of lactic acid bacteria to produce trypsin-like protease. Squares shaded in grey show the two different methods used. A) Method 1: production medium $\mathrm{pH}$ 6, starter culture transferred directly to the production medium as described in previous publication (Wulansari and Wahyuntari 2010); B) Method 2: production medium $\mathrm{pH} 8$, starter cultures were centrifuged prior to transferred to the production medium. 
medium (glucose $0.3 \%$, yeast extract $1 \%$, skim milk $2 \%$, $\mathrm{pH} 6$ ) with inoculum size $10 \%$. The culture was then incubated at $37^{\circ} \mathrm{C}$ with stirring at $50 \mathrm{rpm}$ for $18-24 \mathrm{~h}$.

Method 2. Starter culture was centrifuged at $4{ }^{\circ} \mathrm{C}$, $1400 \mathrm{~g}$ (Hitachi CR216, Rotor R10A2) for $5 \mathrm{~min}$ and the pellet was then used to inoculate the production medium (glucose $0,3 \%$, yeast extract $1 \%$, skim milk $2 \%, \mathrm{pH} 8$ ). The production culture was then incubated at $37^{\circ} \mathrm{C}$, with $50 \mathrm{rpm}$ stirring for $18-24 \mathrm{~h}$. The ratio of starter culture volume : production medium volume is $1: 2$.

Each method was performed at least twice on each strain studied, thus the error bars, as shown in the figures, represent the errors obtain from these repeated experiments. The supernatants were separataed from cells by centrifugation $\left(4^{\circ} \mathrm{C}, 5800 \mathrm{~g}\right.$ (Hitachi CR216, Rotor R10A2), $15 \mathrm{~min}$ ) and the enzyme activities in the supernatants were measured.

Trypsin Activity Assay. Trypsin activity was measured using $\alpha$-N-benzoyl-DL-arginine- $\rho$ nitroanilide (BAPNA) as substrate, using a modified Khantaphant and Benjakul method (Khantaphant and Benjakul 2010). For the assay, $50 \mu \mathrm{L}$ enzyme was mixed with $50 \mu \mathrm{L}$ MilliQ water and $250 \mu \mathrm{L}$ reaction buffer, and left for $5 \mathrm{~min}$ at $37{ }^{\circ} \mathrm{C}$. The reaction buffer used was either TrisHCl $0.05 \mathrm{M} \mathrm{pH} 8$ or citrate buffer $0.05 \mathrm{M} \mathrm{pH} 6$. The $\mathrm{pH}$ of the reaction buffer used for the assay depends on the medium $\mathrm{pH}$ used for the enzyme production. The reaction was initiated by addition of 50 $\mu \mathrm{L}$ BAPNA (Sigma B4875) $2 \mathrm{mg} \mathrm{mL}^{-1}$ and was allowed to continue for $20 \mathrm{~min}$ at $37^{\circ} \mathrm{C}$. To stop the reaction, 50

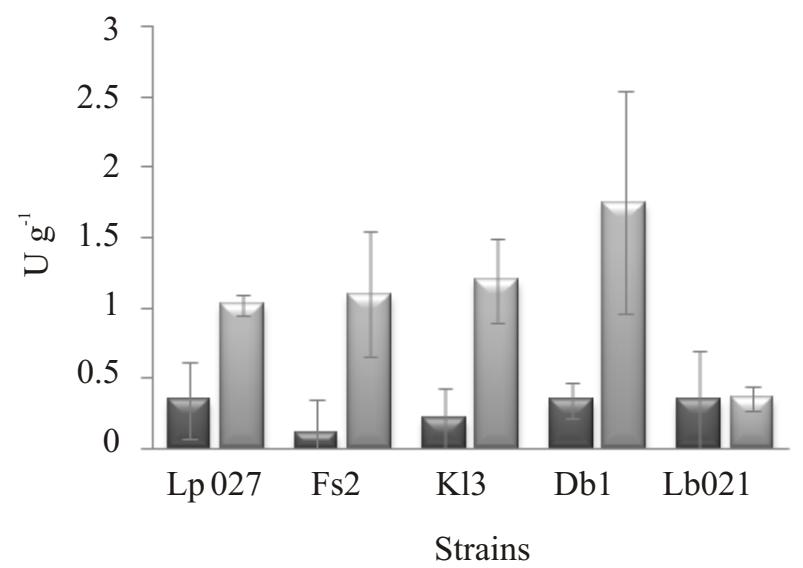

Fig 2 Specific trypsin like activities produced by the isolates. Isolates Lp027, Fs2, K13, and Db1 showed differences in activities when produced using different conditions, and thus studied further. Isolate Lb021 expressed similar activity whether produced using Method 1 or 2 .

Trypsin-like activity when produced using Method 1; Trypsin-like activity when produced using Method 2. $\mu \mathrm{L} 30 \%$ acetic acid was added to the reaction mixture. Production of $\rho$-nitroaniline was measured by measuring the absorbance of the reaction mixture at $410 \mathrm{~nm}$. A blank reaction was conducted in the same manner, except that the sample was added after addition of the acetic acid.

Trypsin activity was calculated as follows:

Trypsin activity $($ unit $/ \mathrm{ml})=\frac{\left(\mathrm{A}-\mathrm{A}_{0}\right) \times \text { mixture volume }(\mathrm{ml}) \times 1000}{8800 \times \text { reaction time }(\mathrm{min}) \times 0.2}$

where $8800\left(\mathrm{~cm}^{-1} \mathrm{M}^{-1}\right)$ was the extinction coefficient of nitroaniline; $\mathrm{A}$ and $\mathrm{A}_{0}$ were the sample and blank absorbances at $\lambda 410$, respectively.

One unit of enzyme activity was defined as the activity that causes the release of $1 \mathrm{nmol} \rho$-nitroaniline per minute.

Trypsin Inhibition Assay. The trypsin inhibition assay was performed using soybean trypsin inhibitor (SBTI) with activity $1000 \mathrm{U} \mathrm{mg}^{-1}$ (Sigma, cat. Number 93620). The assay was performed by dissolving $0.5,1$, $1.5,2,2.5 \mathrm{mg}$ SBTI in $1 \mathrm{~mL}$ enzyme and then left to incubate at room temperature for $15 \mathrm{~min}$. Then, the trypsin activity of the mixture was assayed. The percent inhibition was calculated by the following formula :

$$
\frac{\text { Activity }_{\text {Not-Inhibited }}-\text { Activity }_{\text {Inhibited }}}{\text { Activity }_{\text {Not-Inhibited }}} \times 100 \%
$$

pH and Temperature Profile. The assay to determine the $\mathrm{pH}$ and temperature pofile was performed as described previously by Khantaphant and Benjakul (2010). The optimum temperature as determined by the temperature profile was then used for the measurement to determine the $\mathrm{pH}$ profile.

Trypsin Stability Assay. Stability assays were performed to check trypsin stability in the range of $\mathrm{pH}$ and temperature values tested. The assays were performed based on Khataphant and Benjakul (2010) method. Trypsin stability was determined by measuring the remaining activity after the enzyme was treated at various $\mathrm{pH}$ and temperature values. For thermal stability, the enzyme was incubated at temperatures $24,35,45,50,55,60,65$, and $70^{\circ} \mathrm{C}$ for 30 min before transferred to ice. Then, the residual activity was measured. For pH stability, trypsin was mixed with an equal volume of the appropriate buffer, and left for $30 \mathrm{~min}$ at room temperature. The buffer used was either $0.05 \mathrm{M}$ acetic acid-sodium acetate buffer for $\mathrm{pH}$ 4-6 or $0.05 \mathrm{M}$ Tris $\mathrm{HCl}$ buffer for $\mathrm{pH}$ 7-9 (Khantaphant and Benjakul 2010). The activity was then assayed at the optimal $\mathrm{pH}$ and temperature using (Benzoyl arginine $\rho$ nitroanilide) BAPNA as the substrate. 


\section{RESULTS}

Changing the $\mathrm{pH}$ of the Production Medium and Inoculation Method Changed the $\mathrm{pH}$ of the Culture. The different methods used for trypsin production seemed to affect the medium $\mathrm{pH}$ at the time of inoculation and at the time of harvest. Before used for inoculation, the $\mathrm{pH}$ of starter cultures range between 4.87-5.74. The initial $\mathrm{pH}$ of the production cultures inoculated using Method 1 ranged between 4.95-5.65 and went down to between 3.15-3.85 at the time of harvest. However, when the method was altered, the $\mathrm{pH}$ at time of inoculation increased to between 7.07-7.93 and retained around the level of 6.24-7.15 at the time of harvest. Harvesting was performed when trypsin-like activity reached maximum levels during culture growth (Table 1), as previously optimized. Trypsin-like activity of the cultures were assayed and the results showed that when the bacteria were cultured using Method 2, four strains, namely Lp027, Db1, Fs2, and $\mathrm{K} 13$, showed a considerable increase of trypsin likeactivity. One strain, however, Lb021, showed exactly the same activity whether the enzyme was produced using Method 1 or 2 . The rest of the strains tested showed no considerable trypsin-like activity, whether cultured using Method 1 or 2 .

Table 1 Strains used in the study, their origins (Susanti et al. 2007) and harvest time

\begin{tabular}{llc}
\hline Strains & \multicolumn{1}{c}{ Origin } & $\begin{array}{c}\text { Harvest time } \\
\text { (hours after inoculation) }\end{array}$ \\
\hline Lc 262 & $\begin{array}{l}\text { Fermented glutinous } \\
\text { rice }\end{array}$ & 18 \\
Lp 027 & Growol* & 18 \\
Fs 2 & Infant faeces & 18 \\
Kj 1 & Cheese & 18 \\
Sk 3 & Horse milk & 18 \\
K1 3 & Coconut water & 21 \\
Db 1 & Dadih** & 21 \\
T 3 & Earth & 21 \\
Lb 021 & Fermented glutinous & 24 \\
& rice & \\
Kj 3 & Cheese & 24 \\
K1 2 & Coconut water & 24 \\
\hline
\end{tabular}

* Growol is an Indonesian traditional food made of cassava

**Dadih is an Indonesian traditional drink made of fermented buffalo milk. It is similar to yoghurt in taste and appearance

Changing the $\mathrm{pH}$ of the Production Medium and Inoculation Method Affected the Growth Rate and the Specific Trypsin-Like Activity. The four strains that showed considerable increase of activity were then cultured using two different methods (Method 1 and 2) as described earlier. The culture $\mathrm{pH}$, number of cells and trypsin-like activity were observed every six hours and the values were plotted against time (Fig 3 and 4). The figures clearly show that the change of method used for culturing seemed to have affected not only the culture $\mathrm{pH}$, but also the maximum trypsin-like activity shown by the cultures, although the maximum cells numbers seemed unchanged. Since Method 2 seemed to produce higher trypsin-like activity, this method was then selected as the better of the two methods. Therefore, the characteristics of enzymes produced using method 2 were further explored.

Trypsin-Like Activities Shown by the Four Strains Were Inhibited by Soybean Trypsin Inhibitor (SBTI). Soybean trypsin inhibition assays were performed on enzymes produced using Method 2 to prove that the activity was really caused by trypsin. When treated with SBTI, the trypsin like-activity of the four strains seemed to be considerably inhibited (Fig 5). The percent inhibition also increased, although not to the same extent, with the increase of SBTI concentration.

pH and Temperature Profiles and Stabilities. The $\mathrm{pH}$ and temperature profiles showed that for all strains, the optimum $\mathrm{pH}$ was observed around $\mathrm{pH} 8$ and the optimum temperature was observed around 36-38 ${ }^{\circ} \mathrm{C}$ (Fig 6). The trypsin-like activity seemed to be retained above $60 \%$ when enzymes were heated at temperature range $37-38{ }^{\circ} \mathrm{C}$ (Fig 7). The $\mathrm{pH}$ stability assay shows somehow more divergen result. Although the trypsin-like activity expresed by Fig 2-K13 seemed to be most unaffected when incubated at $\mathrm{pH} 8$ for 30 min prior to activity measurement, this $\mathrm{pH}$ value considerably reduced the activity expressed by strains Lp027 and Db01. On the other hand, the trypsin-like activity expressed by Lp027 seemed to be unaffected after incubation at $\mathrm{pH} 7.5$, whereas, Db1 retained the activity the best at $\mathrm{pH} 7.0$.

\section{DISCUSSION}

Previous publication described the selection of strains producing trypsin-like activity from LAB collections known to express serine protease activity (Wulansari and Wahyuntari 2010). All the trypsin-like activites observed in the previous publication and in the current study were based on extracellular measurements. As described by Liu et al. (2010), there are three major components of LAB proteolytic systems, which are the cell wall bound proteinases initiating the degradation of the extracellular caseins, the peptide transporters taking up the peptides into the 

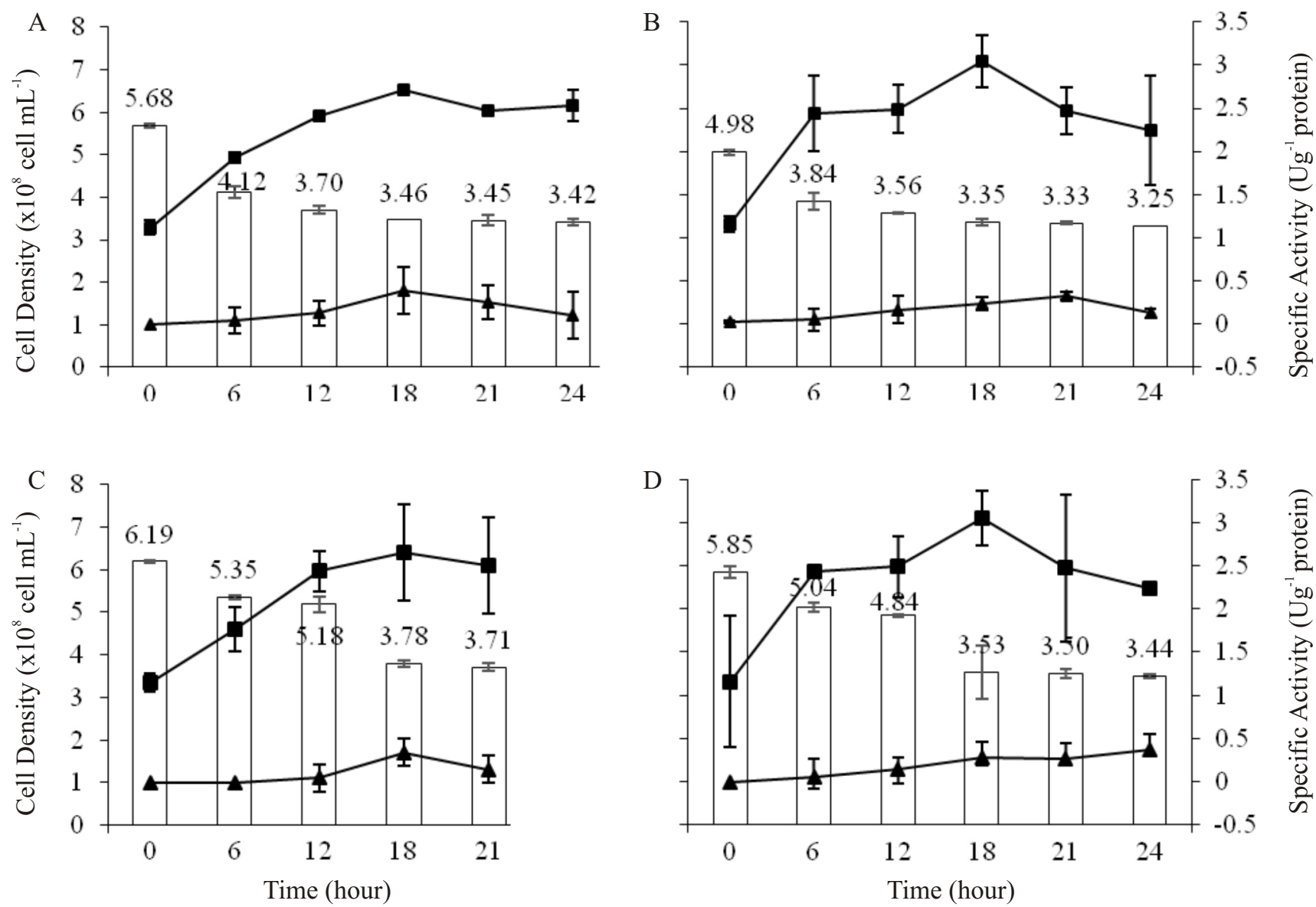

Fig 3 Changes of pH, cell number and trypsin specific activity of strains (A) Lp027, (B) Db1, (C) Fs2, and (D) K13, cultured using Method 1, the culture $\mathrm{pH}$ is represented in bar and the value for each time point is written above the bar, numbers $\left(\mathrm{x} 10^{8}\right.$ cells $\left.\mathrm{mL}^{-1}\right),-$ specific activity $\left(\mathrm{Ug}^{-1}\right.$ protein $)$.

cells, where they would be further digested by various intracellular peptidases (Liu et al. 2010). Searching the NCBI protein database (http://www.ncbi.nlm.nih.gov/ protein) using keywords trypsin and lactic acid bacteria several proteins from LAB reported to show trypsinlike activity were identified. This, obviously, is relevant to the observed trypsin like activity observed in some of the strains screeed earlier (Wulansari and Wahyuntari 2010).

In the previous work, production medium with $\mathrm{pH}$ 6 was used (Wulansari and Wahyuntari 2010). This $\mathrm{pH}$ value was used because the cultures were initially grown in MRS medium ( $\mathrm{pH} \mathrm{6)}$ prior to inoculation to the production medium. In addition, $\mathrm{pH}$ around 6 was considered the optimum $\mathrm{pH}$ required for the growth of lactic acid bacteria (Hutkins et al. 1993). The production medium was inoculated by directly transferring $10 \%$ inoculum previously grown in MRS edium (Method 1), without separating the cells from the growth medium. Using this method, the production medium $\mathrm{pH}$ immediately dropped to between 4.98-6.19 (Fig 3). The $\mathrm{pH}$ further decreased until it reached between 3.25-3.71 at the end of the fermentation (Fig
3 ), which is probably due to the secretion of lactic acid by the bacteria. This condition is, of course, not good for the survival of the bacteria, since they are very prone to cell damage when the final medium $\mathrm{pH}$ goes below pH 5.0 (Hutkins and Nannen 1993). The low pH phenomenon was observed on cultures grown using Method 1. The low $\mathrm{pH}$ of the cultures could have considerably reduced cell viability, since lactic acid bacteria in general grow at $\mathrm{pH}$ range 4.5-7.0 (Hutkins and Nannen 1993).

Regardless of the cells viability, low $\mathrm{pH}$ might also have affected the trypsin-like activity. As is widely known, trypsin works optimally at $\mathrm{pH}$ around 7.5-8.5 (Koutsopoulos et al. 2007). At pH lower or higher than this range the activity would most likely be reduced, thus the lower $\mathrm{pH}$ might have considerably reduced the trypsin-like activity expressed by the strains tested.

Harvesting the cells by centrifugation was aimed at isolating cells from the acidic environment of the growth medium (see Table 2 for $\mathrm{pH}$ of the starter culture). By harvesting the cells prior to their use for inoculation, the amount of growth medium, i.e. acidic medium, being carried over to the production medium 


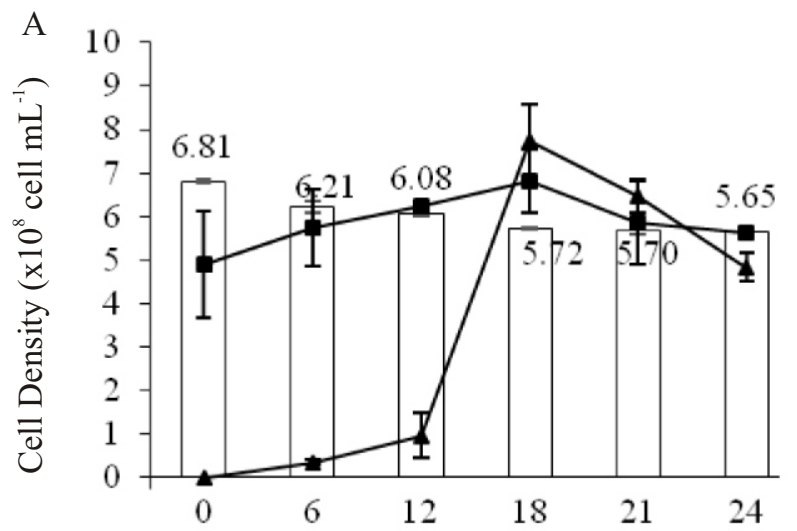

B
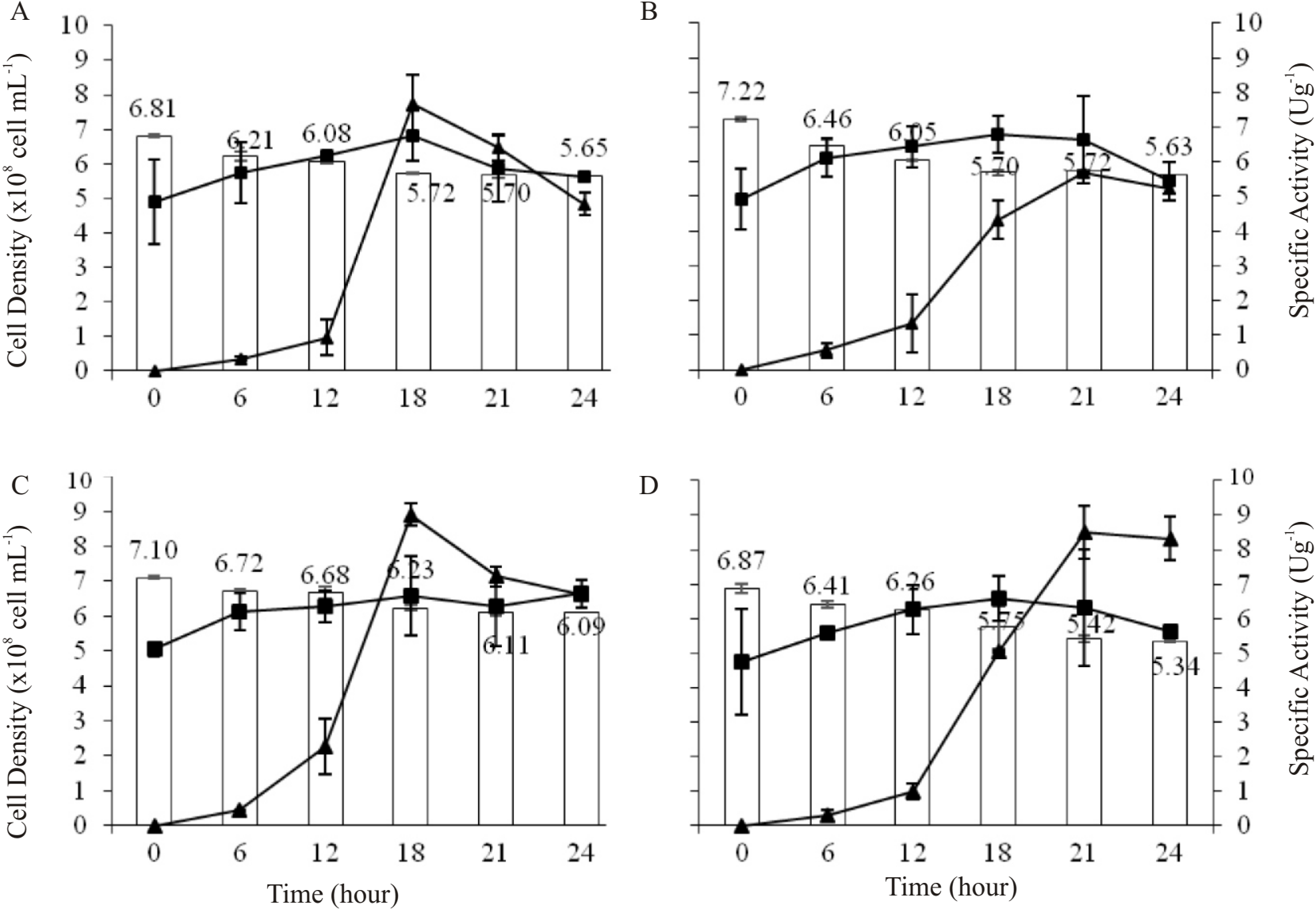

$\mathrm{D}$

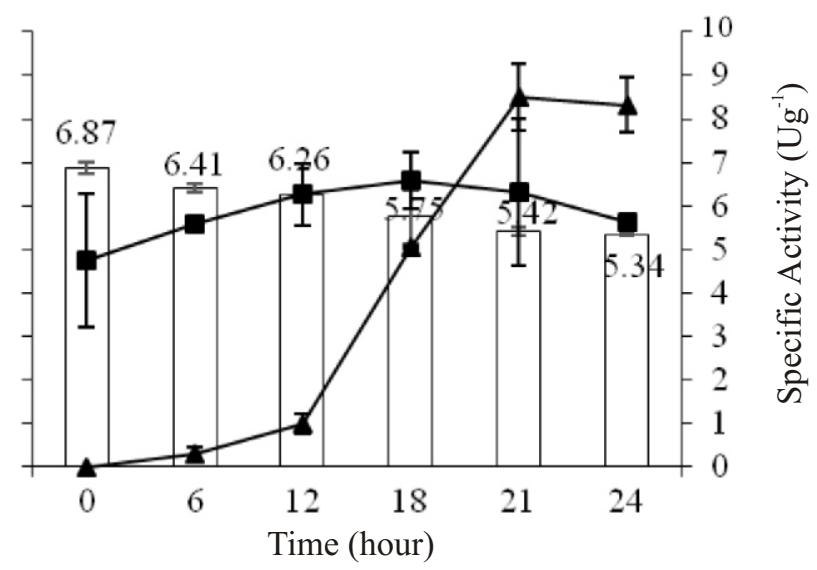

Fig 4 Changes of $\mathrm{pH}$, cell number and trypsin specific activity of strains (A) Lp027, (B) Db1, (C) Fs2, and (D) K13, cultured using Method 2, the culture $\mathrm{pH}$ is represented in bar and the value for each time point is written above the bar, numbers $(\mathrm{x} 108 \mathrm{cells} / \mathrm{ml})$, - $\mathbf{-}$ specific activity $\left(\mathrm{Ug}^{-1}\right.$ protein $)$.

was minimised. Thus, the sudden decrease of production medium $\mathrm{pH}$ immediately after inoculation as demonstrated when Method 1 was used ( $\mathrm{pH}$ after inoculation 4.98-6.15) was prevented. Since during their growth lactic acid bacteria produce lactic acid, the end $\mathrm{pH}$ of the production medium was 3.25-3.71 when Method 1 was used. On the other hand, when Method 2 was used, the production medium $\mathrm{pH}$ was retained at around 7 at the beginning and around 6 at the end of the fermentation. Although the extent of $\mathrm{pH}$ decrease in Method 1 and 2 was more or less equal (i.e. around 1-2 $\mathrm{pH}$ Unit), the end $\mathrm{pH}$ in Method 2 remained above 6. The relatively more stable $\mathrm{pH}$ seemed to have been able to retain the trypsin like-activities expressed by the culture when produced using Method 2.

There could be two underlying reasons why the trypsin like-activities were higher in Method 2. It was possible that at the higher $\mathrm{pH}$, more bacteria could survive and so more enzymes were produced, or that at higher $\mathrm{pH}$ the enzyme was more stable compared to at lower $\mathrm{pH}$, that the typsin like-activities were higher. Looking at the numbers of cells at the time of harvest

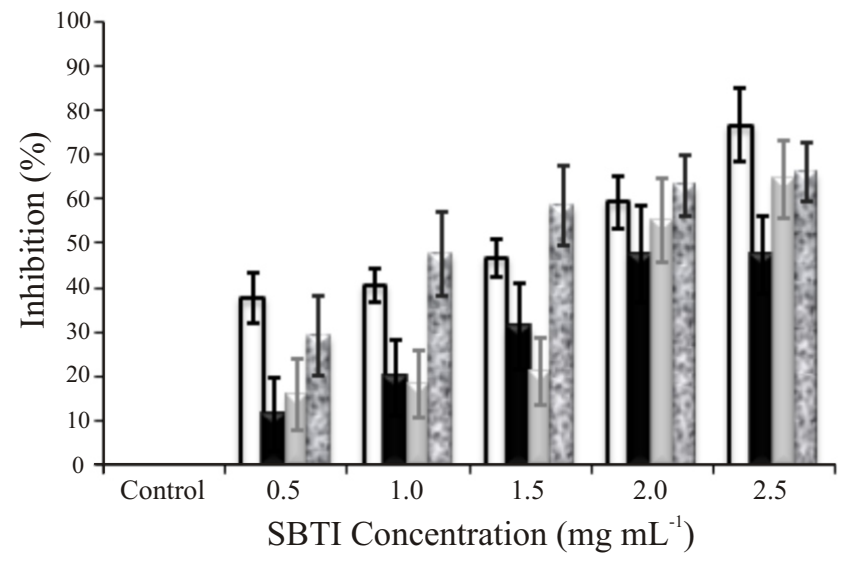

Fig 5 Percent inhibition by soybean trypsin inhibitor (SBTI) of enzyme activity produced using Method 2, QLp027, $\square \mathrm{Db} 1, \mathrm{Fs} 2, \boldsymbol{\mathrm { K }} 13$.

(i.e. $18 \mathrm{~h}$ ), it seems that the difference in cell numbers was unlikely to be the reason, because at $18 \mathrm{~h}$ the cell densities of all cultures, whether grown at $\mathrm{pH} 6$ or 8 , were approximately the same at around $7 \times 10^{8}$ (Fig 3 and 4). To further prove that the enzyme activities observed were really produced by trypsin, trypsin inhibition assays using soy bean trypsin inhibitor 

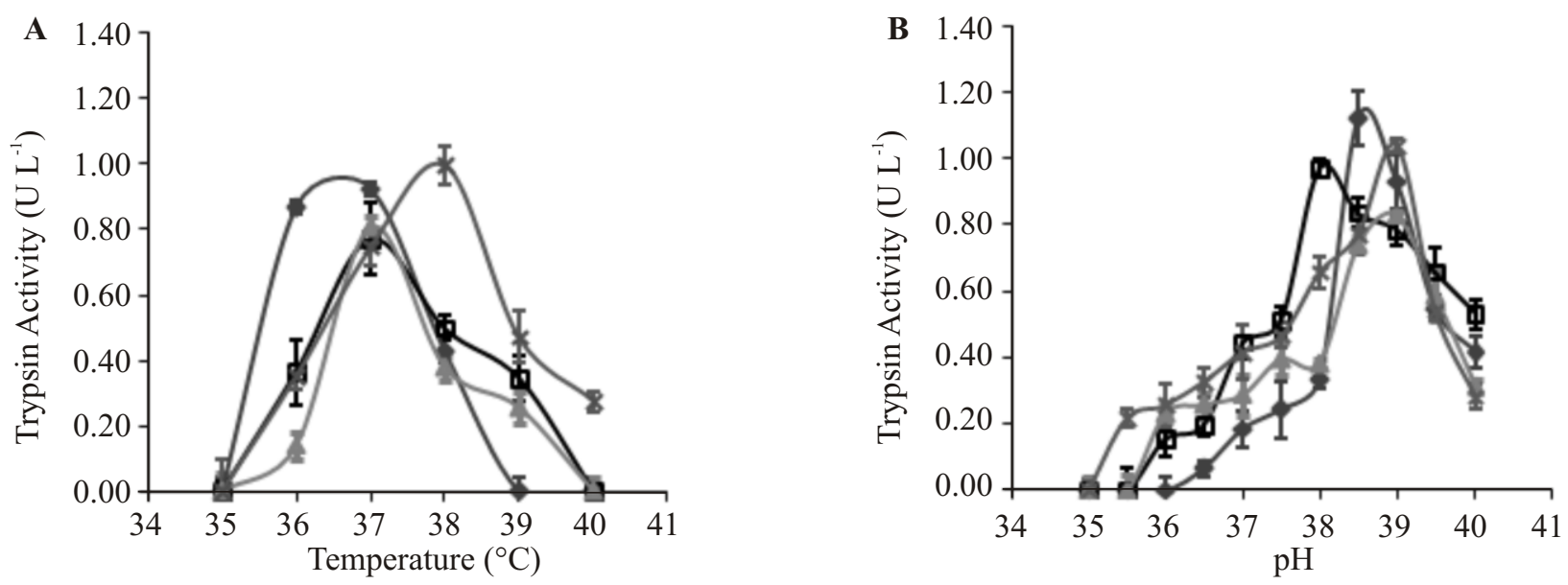

Fig 6 Temperature(A) and pH (B) profile of the trypsin like activity of the enzymes produced using Method 2. The assays were performed as described previously by Khantaphant and Benjakul (2010). The optimum temperature as determined by the temperature profile was then used for the measurement to determine the pH profile. $\sim$ Lp027, $\mathbf{Z D b} 1, \quad$-Fs2, $*$ KK13.
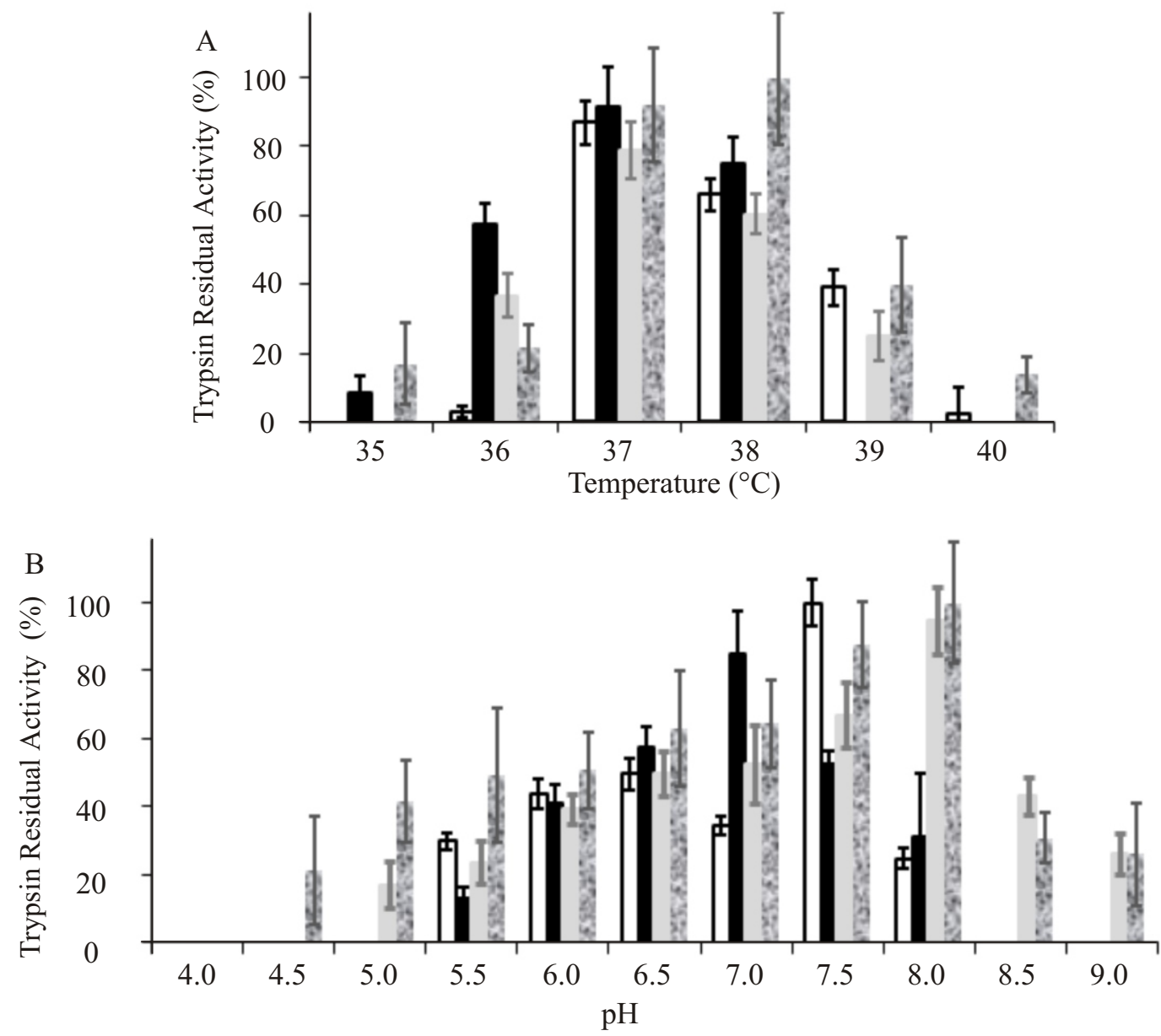

Fig 7 Residual activity of trypsin produced by Method 2, after treatment with various temperature (A) and pH (B). For thermal stability, the enzyme was incubated at temperatures $25,35,45,50,55,60,65$, and $70{ }^{\circ} \mathrm{C}$ for 30 min before transferred to ice. Then, the residual activity was measured. For $\mathrm{pH}$ stability, trypsin was mixed with an equal volume of the appropriate buffer (either 0.05M acetic acid - sodium acetate buffer for $\mathrm{pH} 4$ - 6 or $0.05 \mathrm{M}$ Tris HCl buffer for $\mathrm{pH} 7$ - 9 (Khantaphant and Benjakul 2010)), and left for $30 \mathrm{~min}$ at room temperature. The activity was then assayed at the optimal $\mathrm{pH}$ and temperature (as determined by temperature and pH profile analyses) using BAPNA as the substrate. $\square$ Lp027, $\square$ Db1, $\square$ Fs2, $\mathbf{2}$ K13.

(SBTI), were preformed (Fig 5). The assays indicated that the activities expressed by all strains were inhibited by SBTI, although to a different extent with different cultures. The amount of SBTI required for the inhibition, however, was higher in comparison to the amount required to inhibit trypsin from other sources 
(Struthers and MacDonald 1983), including bacteria (Takada et al. 2000; Hansen et al. 2005).

The trypsin like-activities of the strains were stable at range between $36-38^{\circ} \mathrm{C}$ and the effect of temperature treatment was least when the enzymes was treated at 37 ${ }^{\circ} \mathrm{C}$ for 30 min prior to measurement. The $\mathrm{pH}$ stability studies showed that the trypsin like-activities were still detectable after treatment at $\mathrm{pH}$ range $5.5-8$ for $30 \mathrm{~min}$ prior to activity measurement (Fig 7). The $\mathrm{pH}$ and temperature profiles also showed more or less the same patterns, with optimum temperature around $36-38^{\circ} \mathrm{C}$, optimum $\mathrm{pH}$ aroun 7-8. This is relevant to the general knowledge that trypsin has an optimum temperature of $37{ }^{\circ} \mathrm{C}$ and an optimum $\mathrm{pH}$ between 7.5-8.5 (Koutsopoulos et al. 2007). Considering the results of inhibition experiments, as well as the patterns of temperature and $\mathrm{pH}$ profile and stability, shows that the activities observed were really expressed by trypsin from the lactic acid bacteria. N-terminal sequencing would be necessary to be entirely sure the protein is pure enzyme.

In conclusion, it is clear that the methods used for inoculation of production medium, in addition to the production medium $\mathrm{pH}$, affect the trypsin-like activity. As clearly and thoroughly presented above, using production medium with $\mathrm{pH} 8$ and separation of cells from growth medium prior to inoculation to the production medium, increased the trypsin-like activity produced. This is a better method for trypsin production from lactic acid bacteria.

\section{REFERENCES}

Bintsis T, Vafopoulou-Mastrojiannaki A, LitopoulouTzanetaki E, Robinson RK. 2003. Protease, peptidase and esterase activities by lactobacilli and yeast isolates from Feta cheese brine. J Appl Microbiol. 95(1): 68-77.

Bradford MM. 1976. A rapid and sensitive method for the quantitation of microgram quantities of proteinutilizing the principle of protein-dye binding. Anal Biochem. 72: 248-254.

Caplice E, Fitzgerald GF. 1999. Food fermentations: role of microorganisms in food production and preservation. Int J Food Microbiol. 50(1-2): 131-149.

Courtin P, Monnet V, Rul F. 2002. Cell-wall proteinases PrtS and PrtB have a different role in Streptococcus thermophilus/Lactobacillus bulgaricus mixed cultures in milk. Microbiology. 148(Pt 11):3413-3421.

Hansen KK, Sherman PM, Cellars L, Andrade-Gordon P, Pan $\mathrm{Z}$, et al. 2005. A major role for proteolytic activity and proteinase-activated receptor-2 in the pathogenesis of infectious colitis. Proc Natl Acad Sci U S A. 102: 83638368. doi: 10.1073/pnas.0409535102.
Haq Iu, Mukhtar H. 2006. Biosynthesis of protease from Lactobacillus paracasei: kinetic analysis of fermentation parameters. Indian J Biochem Biophys. 43(6): 377-381.

Hutkins RW, Nannen NL. 1993. pH Homeostasis in lactic acid bacteria. J. Dairy Sci. 76: 2354 - 2365.

Khantaphant S, Benjakul S. 2010. Purification and characterization of trypsin from the pyloric caeca of brownstripe red snapper (Lutjanus vitta). Food Chemistry. 120(3): 658-664.

Koutsopoulos S, Patzsch K, Bosker WTE, Norde W. 2007. Adsorption of trypsin on hydrophilic and hydrophobic surfaces. Langmuir 23: 2000-2006. doi: $10.1021 / 1 \mathrm{a} 062238 \mathrm{~s}$.

Liu M, Bayjanov J, Renckens B, Nauta A, Siezen R. 2010. The proteolytic system of lactic acid bacteria revisited: a genomic comparison. BMC Genomics. 11(1): 36.

Oberg CJ, Broadbent JR, Strickland M, McMahon DJ. 2002. Diversity in specificity of the extracellular proteinases in Lactobacillus helveticus and Lactobacillus delbrueckii subsp. bulgaricus. Lett Appl Microbiol. 34(6): 455-460.

Pezzilli R. 2009. Chronic pancreatitis: maldigestion, intestinal ecology and intestinal inflammation. World $\mathbf{J}$ Gastroenterol. 15(14): 1673-1676.

Piuri M, Sanchez-Rivas C, Ruzal SM. 2003. Adaptation to high salt in Lactobacillus: role of peptides and proteolytic enzymes. J Appl Microbiol. 95(2): 372-379.

Struthers BJ, MacDonald JR. 1983. Comparative inhibition of trypsins from several species by soybean trypsin inhibitors. J Nutr. 113(4): 800-804.

Susanti I, Kusumaningtyas RW, Ilaningtyas F. 2007. Uji sifat probiotik bakteri asam laktat sebagai kandidat bahan pangan fungsional. [Probiotic character assays of lactic acid bacteria as candidates of functioned food sources]. J Teknologi dan Industri Pangan. 18(2): 89-95.

Takada K, Hirasawa M. 2000. Expression of trypsin-like activity by the genera Corynebacterium, Actinomyces in canine periodontitis. J Med Microbiol. 49(7): 621625.

Waljee AK, Dimagno MJ, Wu BU, Schoenfeld PS, Conwell DL. 2009. Systematic review: pancreatic enzyme treatment of malabsorption associated with chronic pancreatitis. Aliment Pharmacol Ther. 29: 235-246. doi: 10.1111/j.1365-2036.2008.03885.x.

Whitcomb DC, Lowe ME. 2007. Human pancreatic digestive enzymes. Dig Dis Sci. 52: 1-17. doi: 10.1007/ s10620-006-9589-z.

Wulansari D, Wahyuntari SB. 2010. Selection of trypsin likeprotease producing lactic acid bacteria and characterisation of the enzyme. In: Wahyuntari B, Pawiroharsono S, Setyahadi S, Helianti I, Trismilah, editors. Conference on Industrial Enzyme and Biotechnology; 2010 August 3, Serpong, Indonesia. p 30-36. 